\title{
Morfometri Dan Komposisi Isi Lambung Katsuwonus pelamis Yang Didaratkan Di Pantai Puger Jember Jawa Timur
}

\author{
Lutfil Hakim Baidhowie*, Sri Rejeki, Hadi Endrawati \\ Departemen IImu Kelautan, Fakultas Perikanan dan Ilmu Kelautan, Universitas Diponegoro \\ Jl. Prof.H.Soedarto S.H, Tembalang,Semarang, Jawa Tengah 50275 Indonesia \\ ${ }^{*}$ Corresponding author, e-mail : lutfilhakim.baidhowie@gmail.com
}

\begin{abstract}
ABSTRAK : Ikan Cakalang yang ditemukan di pantai Puger ini memiliki ukuran yang beragam. Nama ilmiah disebut dengan (Katsuwonus pelamis) diambil dari bahasa Jepang yang artinya ikan keras. Umumnya ikan cakalang termasuk ikan perenang cepat dan mempunyai sifat rakus dalam mencari makan. Ikan cakalang ini mencari makan berdasarkan penglihatan dan rakus terhadap mangsanya. Penelitian ini bertujuan untuk mengetahui kebiasaan makan ikan cakalang (Katsuwonus pelamis) berbagai ukuran yang didaratkan di perairan pantai Puger, Kabupaten Jember. Metode yang digunakan dalam penelitian ini adalah metode frekuensi kejadian. Sampel ikan sebanyak 107 ekor diambil pada tanggal 31 Oktober - 1 Desember 2018. Pengambilan data ikan dilaksanakan di lapangan dengan mengukur berat dan panjang total ikan. Pengamatan lambung ikan dilakukan dengan cara membedah tubuh ikan dan dianalisis komposisi yang terdapat pada lambung ikan cakalang. Dengan menggunakan metode frekuensi kejadian tiap isi yang terdapat pada lambung ikan dicacat dan dinyatakan dalam persen. Hasil dari penelitian menunjukkan dari 107 ekor ikan cakalang yang diamati diketahui distribusi panjang dan berat berkisar 51-92 cm dan kisaran berat 4700-7200 gram. Sedangkan isi yang terdapat pada lambung ikan cakalang adalah ikan,cumi dan udang. Hasil dari perhitungan yang telah dilakukan dapat dijelaskan bahwa organisme ikan yang komposisinya paling banyak dengan nilai persentase pada tanggal 31 bulan oktober sebesar $74 \%$, tanggal 7 bulan November $85 \%$, tanggal 13 bulan November sebesar $91 \%$, tanggal 19 bulan November sebesar $87 \%$, tanggal 25 bulan November sebesar $83 \%$ dan tanggal 1 Desember nilai persentase $89 \%$. Ikan cakalang yang terdapat di Pantai puger memiliki petrumbuhan yang bersifat alometrik negatif dengan nilai b sebesar $-1,2113$ dan a sebesar 0,7585 sehingga diketahui pertumbuhan panjang tubuh ikan lebih cepat dari pertumbuhan berat ikan.
\end{abstract}

Kata kunci : Katsuwonus pelamis; Morfometri; Lambung ikan; Jember

\section{Morphometry and Composition of the Gastric Hull Katsuwonus pelamis Landing on the Puger Coast of Jember, East Java}

\begin{abstract}
Skipjack found on Puger beach have a variety of sizes. The scientific name of it ca lled (Katsuwonus pelamis), it is taken from Japanese which means hard fish. Generally, skipjack is also be included as fast swimmer fish and it has a greedy nature in foraging. This skipjack look for the meal is based on vision and they are greedy for their prey. This study aims to determine the eating habits of skipjack (Katsuwonus pelamis) of various sizes that are landed in the coastal waters of Puger, Jember Regency. The method used in this study is the method of frequency of events. There are 107 fish samples that were taken on 31 October - 1 December 2018. The taking of the data was carried out in the field by measuring the total weight and length of the fish. Observation of fish stomach was done by dissecting the body of the fish and analyzing the composition contained in the stomach of skipjack. Using the method of frequency of occurrence, each content contained in the fish stomach is deformed and expressed in percent. The results of the study showed that 107 of the skipjack that is observed, were known to have a long distribution and weight ranging from 51-92 cm and a weight range of 4700-7200 grams. While the contents contained in the stomach of skipjack are fish, squid and shrimp. The results of the calculations that have been made can be explained that the fish organisms whose composition is the most with a percentage value on October 31 of $74 \%$, November 7, 85\%, November 13 of $91 \%$, November 19 of $87 \%$, the 25 th of November is $83 \%$ and December 1 is a percentage of $89 \%$. The skipjack found
\end{abstract}


in the puger beach has plants that are negative allometric with a value of $b$ of -1.2113 and $a$ of 0.7585 so it is known that the growth of fish body length is faster than the growth of fish weight.

Keywords : Katsuwonus pelamis; Morfometry; Fish stomach; Jember

\section{PENDAHULUAN}

Ikan cakalang nama ilmiah disebut (Katsuwonus pelamis) diambil dari bahasa Jepang yang artinya ikan keras. Seperti halnya dengan sumber daya perikanan laut lainnya sumber daya perikanan cakalang dapat pulih kembali (renewable), namun demikian eksploitasi tanpa upaya pengendalian dapat menyebabkan degradasi populasi ikan ini. Oleh karena itu diperlukan perhatian yang sungguh-sungguh dalam pengelolaannya agar pengusahaan dan potensinya tetap lestari (Mantjoro, 2013).

Ikan cakalang akan membentuk gerombolan ikan pada saat aktif mencari makan. Pada umumnya ikan cakalang termasuk ikan perenang cepat dan mempunyai sifat makan yang rakus. Ikan jenis ini sering bergerombol yang hampir bersamaan melakukan ruaya disekitar pulau maupun jarak jauh dan senang melawan arus, ikan ini biasa bergerombol diperairan pelagis hingga kedalaman 200 meter. Ikan ini mencari makan berdasarkan penglihatan dan rakus akan terhadap mangsanya (Purwasasmita, 1993).

Pergerakan migrasi kelompok ikan cakalang di wilayah perairan Indonesia mencakup wilayah perairan pantai, teritorial dan Zona Ekonomi Eklusif (ZEE) Indonesia. Keberadaan mereka di suatu perairan sangat bergantung pada beberapa hal yaitu kondisi hidro-oseanografi perairan. Pada wilayah perairan ZEE Indonesia, migrasi jenis cakalang di perairan Indonesia merupakan bagian dari jalur migrasi karena wilayah Indonesia terletak pada lintasan perbatasan perairan antara samudera Hindia dan Samudera Pasifik (FAO, 2006).

Ikan Cakalang merupakan ikan karnivora dan menempati tempat teratas dalam rantai makanan di laut. Ikan cakalang menggunakan gerakan yang hebat dalam kolom air untuk menangkap makanannya. Pergerakan ikan cakalang naik dan turun dikolom air juga sesuai dengan ketersediaan makanan. Sepanjang hari ikan cakalang cenderung menyelam ke bawah dan malam hari naik kepermukaan untuk makan dan ketengah untuk menghindari kompetisi makanan (Uktolseja, 1997).

Pelabuhan Perikanan Puger yang terdapat di Kecamatan Puger Kabupaten Jember ini merupakan salah satu wilayah di Provinsi Jawa Timur yang memiliki potensi sumber daya alam yang melimpah. Potensi sumber daya alam yang cukup potensial untuk dikembangkan adalah sektor perikanan yang merupakan salah satu wilayah yang berbatasan langsung dengan pantai pesisir selatan jawa bagian timur. Selama ini sektor yang telah dikembangkan di wilayah Puger adalah sektor perikanan laut.

\section{MATERI DAN METODE}

Materi penelitian yang digunakan pada ikan cakalang (Katsuwonus pelamis) untuk mengetahui ukuran panjang ikan cakalang dan isi lambung untuk mengetahui jenis kebiasaan makan pada ikan cakalang yang diambil di tempat pelelngan ikan pelabuhan Puger Kabupaten Jember. Metode penelitian yang digunakan adalah metode frekuensi kejadian kejadian dengan tiap-tiap isi alat pencernaan ikan dicatat, masing-masing organisme yang terdapat dalam sejumlah alat pencernaan yang berisi organisme sebagai bahan makanannya dicatat dan dinyatakan dalam persen.Penentuan lokasi penelitian (Gambar 1)dilakukan dengan menggunakan metode Frekuensi kejadian yaitu teknik pengambilan dengan mencatat terdapatnya organisme yang terdapat dalam alat pencernaan ikan dan dinyatakan dalam persen (Effendie, 1979).

Pengambilan sampel dilakukan dengan cara ikan didapatkan dari pengepul ikan di pelabuhan atau TPI Puger, Kabupaten Jember. Sampel ikan yang diambil adalah ikan-ikan yang telah didaratkan di pelabuhan ikan. Pengambilan data ikan dilaksanakan di lapangan dengan mengukur berat dan panjang total ikan. Identifikasi isi lambung dari ikan cakalang yang telah 
ditangkap kemudian akan dianalisis komposisi isi lambung dengan metode frekuensi kejadian (Effendi, 1979).

Setiap individu sampel ikan dilakukan pengukuran panjang total dimana panjang ikan didapatkan dengan mengukur jarak garis lurus antara ujung kepala yang terdepan dengan ujung sirip ekor yang paling belakang.

Pengambilan data ikan dilaksanakan di lapangan dengan mengukur berat dan panjang total ikan dan mengukur frekuensi kejadian dengan tiap-tiap isi alat pencernaan ikan dicatat, masingmasing organisme yang terdapat dalam sejumlah alat pencernaan yang berisi organisme sebagai bahan makanannya dicatat. Effendie (1979) menyatakan hubungan antara panjang ikan dan berat ikan dihitung berdasarkan persamaan :

$$
W=a L^{b}
$$

Keterangan : $\mathrm{W}=$ berat tubuh $(\mathrm{gr}) ; \mathrm{L}=$ panjang tubuh $(\mathrm{mm}) ; \mathrm{a}=$ konstanta; $\mathrm{b}=$ konstanta

Korelasi parameter dari hubungan panjang dan berat dapat dilihat dari nilai konstanta $b$ sebagaimana penduga tingkat kedekatan hubungan kedua parameter apabila : $b=3$, memiliki hubungan isometrik, maka pertumbuhan ikan tidak berubah bentuk, jadi pertambahan panjang ikan sebanding dengan pertambahan beratnya; $b \neq 3$, memiliki hubungan allometrik, $b>3$ allometrik positif, maka ikan tersebut gemuk, jadi pertumbuhan berat lebih cepat dari pertumbuhan panjang; $b<3$ allometri negatif, maka ikan tersebut kurus, jadi pertambahan panjang lebih cepat dari pertambahan berat (Carlander, 1969). Metode frekuensi kejadian dirumuskan sebagai berikut :

$$
F K=\frac{N i}{I} x 100 \%
$$

Keterangan $: F K=$ Frekuensi kejadian; $\mathrm{Ni}=$ Jumlah total satu jenis organisme; $\mathrm{I}=$ Total lambung berisi

\section{HASIL DAN PEMBAHASAN}

Hasil data yang terdapat pada pantai Puger Kabupaten Jember yang telah dihitung hubungan antara panjang total ikan dengan berat tubuh semua ikan cakalang maka didapatkan nilai-nilai untuk pengambilan data pada tanggal 31 Oktober 2018 sampai tanggal 1 Desember 2018 adalah sebagai berikut dimana nilai dari a sebesar $-1,2113$ dan nilai $b$ sebesar
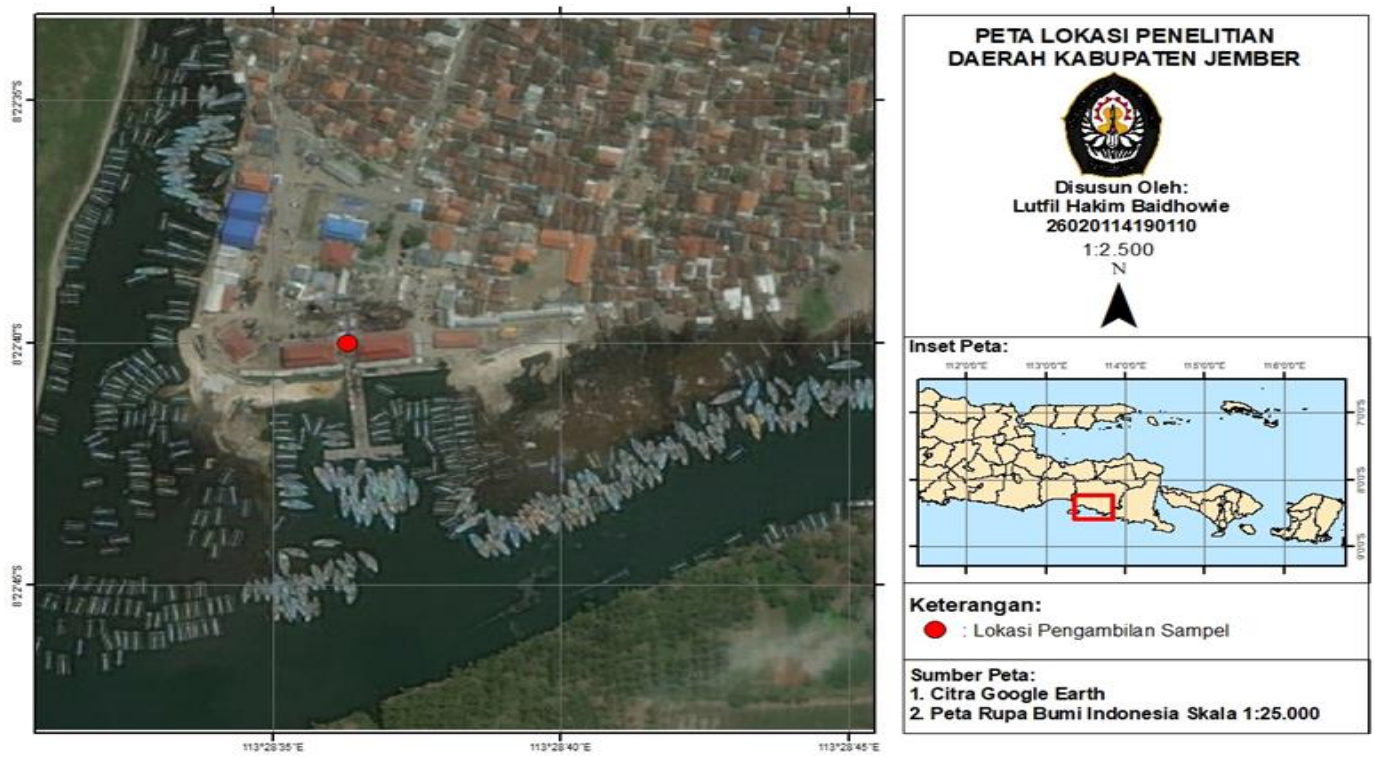

Gambar 1. Peta Lokasi Penelitian 
0,7585 serta bersifat allometrik negatif yang berarti pertumbuhan panjang dari ikan cakalang lebih cepat daripada pertumbuhan berat tubuh ikan.

\section{Distribusi Ikan Cakalang}

Ikan Cakalang yang telah diambil sebanyak 107 ekor sampel, didapatkan data berupa panjang total ikan, berat ikan, data komposisi isi lambung dan makanan ikan dalam lambung (Gambar 3). Data sebaran frekuensi ikan Cakalang berdasarkan panjang total dan berat. Pola distribusi dari ikan menurut pendapat Merta (1982), secara alami akan berkaitan dengan ketersediaan makanannya di alam sehingga dapat diketahui juga bagaimana pola rantai makanan di alam. Sampel yang telah didapatkan mengindikasikan bahwa ikan Cakalang yang didaratkan di TPI Puger Jember adalah ikan-ikan dengan kisaran panjang total $51-92 \mathrm{~cm}$.

. Jumlah sampel populasi ikan cakalang yang telah didapatkan pada saat pengambilan data, jumlah terbanyak adalah pada kisar panjang ikan kelas kecil antara 51-65 cm dengan total jumlah ikan yang didapat adalah sebanyak 55 ekor, jumlah kedua adalah untuk kisaran panjang ikan kelas sedang 66-77 cm dengan jumlah ikan sebanyak 43, diposisi terakhir adalah untuk kisaran panjang tubuh ikan kelas besar 78-92 cm dengan didapatkan 9 ekor ikan.

Berdasarkan Gambar 4 jumlah sampel populasi ikan cakalang dengan kisaran berat yang berbeda yang telah didapatkan pada saat pengambilan data adalah jumlah terbanyak untuk 107 ekor ikan yang didapatkan adalah untuk kisaran berat tubuh ikan kecil 4700-5900 gram didapatkan 31 ekor ikan, kemudian untuk kisaran berat sedang 6000-6700 gram didapatkan 42 ekor ikan dan untuk kisaran berat tubuh ikan besar 6800-7200 gram didapatkan 34 ekor ikan.

\section{Pengukuran Frekuensi Kejadian}

Hasil dari tabel diatas, diketahui bahwa dari semua sampel ikan Cakalang dengan lambung berisi (107) lambung di hitung dengan pengambilan perbedaan setiap bulan berdasarkan tabel nilai frekuensi kejadian diatas diketahui bahwa organisme ikan yang ditemukan pada lambung ikan cakalang dengan tanggal 31 Oktober 2018 terdapat dengan persentase Ikan 74\%, Udang 7\%, Cumi $11 \%$ dan Unidentified $8 \%$.. Di bulan yang berbeda dengan tanggal 07 November 2018 terdapat persentase Ikan 85\%, Udang 8\%, Cumi 3\% dan Unidentified 4\%. Tanggal 13 November 2018 terdapat persentase Ikan 91\%, Udang 3\%, Cumi 2\%, Unidentified 4\%. Tanggal 19 November 2018 terdapat Persentase Ikan 87\%, Udang 3\%, Cumi 2\% dan Unidentified 8\%. Tanggal 25 November 2018 terdapat persentase Ikan 83\%, Udang 4\%, Cumi 5\% dan UN 8\%. Di bulan yang berbeda 1 Desember terdapat persentase Ikan sebesar $89 \%$, Udang 1\%, Cumi 3\% dan Unidentified $7 \%$.

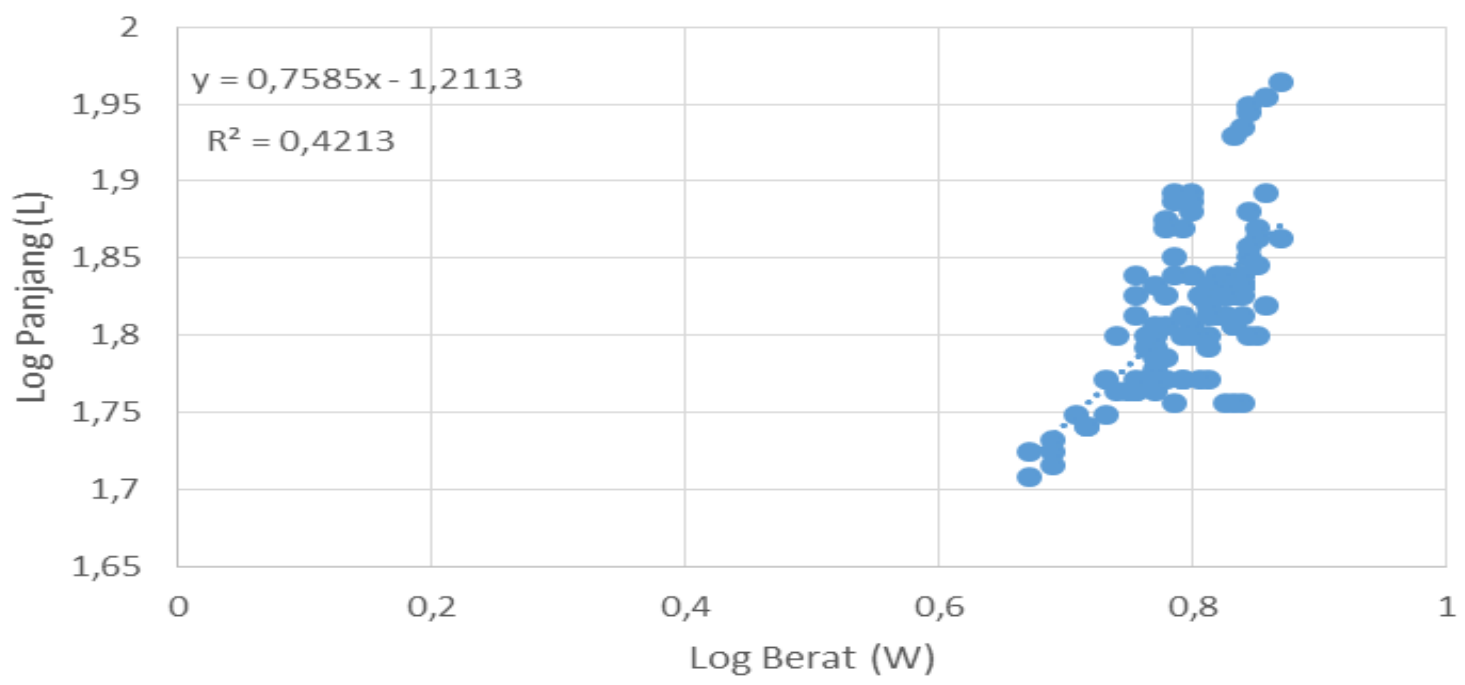

Gambar 2. Hubungan Panjang dan Berat Ikan Cakalang di TPI Puger Kabupaten Jember 


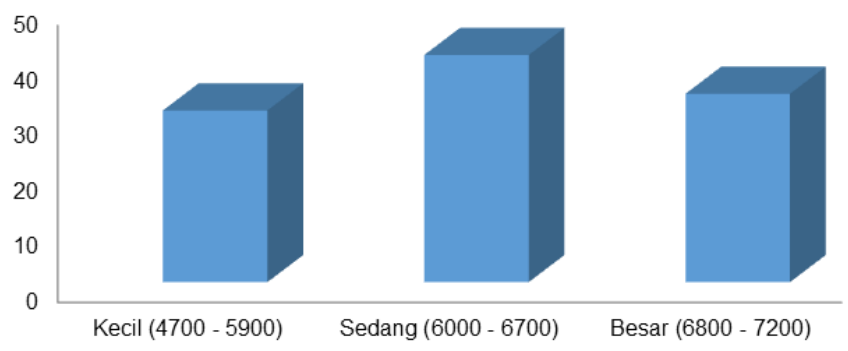

Gambar 3. Sebaran Frekuensi Ikan Cakalang Berdasarkan panjang Total di TPI Puger, Jember (Oktober - Desember)

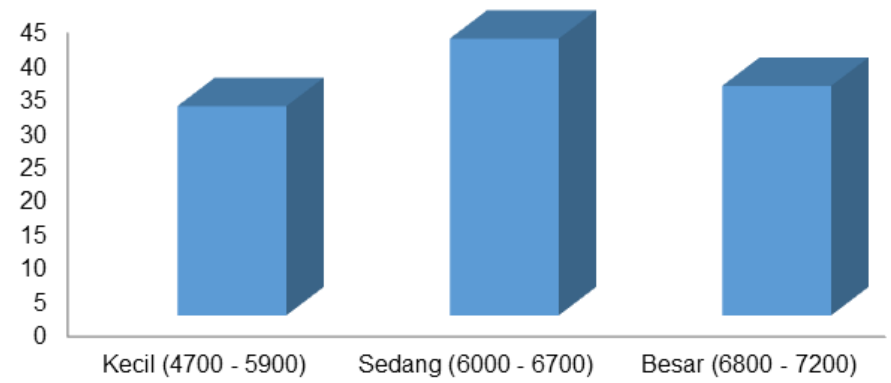

Gambar 4. Sebaran Frekuensi lkan Cakalang Berdasarkan Berat Total di TPI Puger, Jember
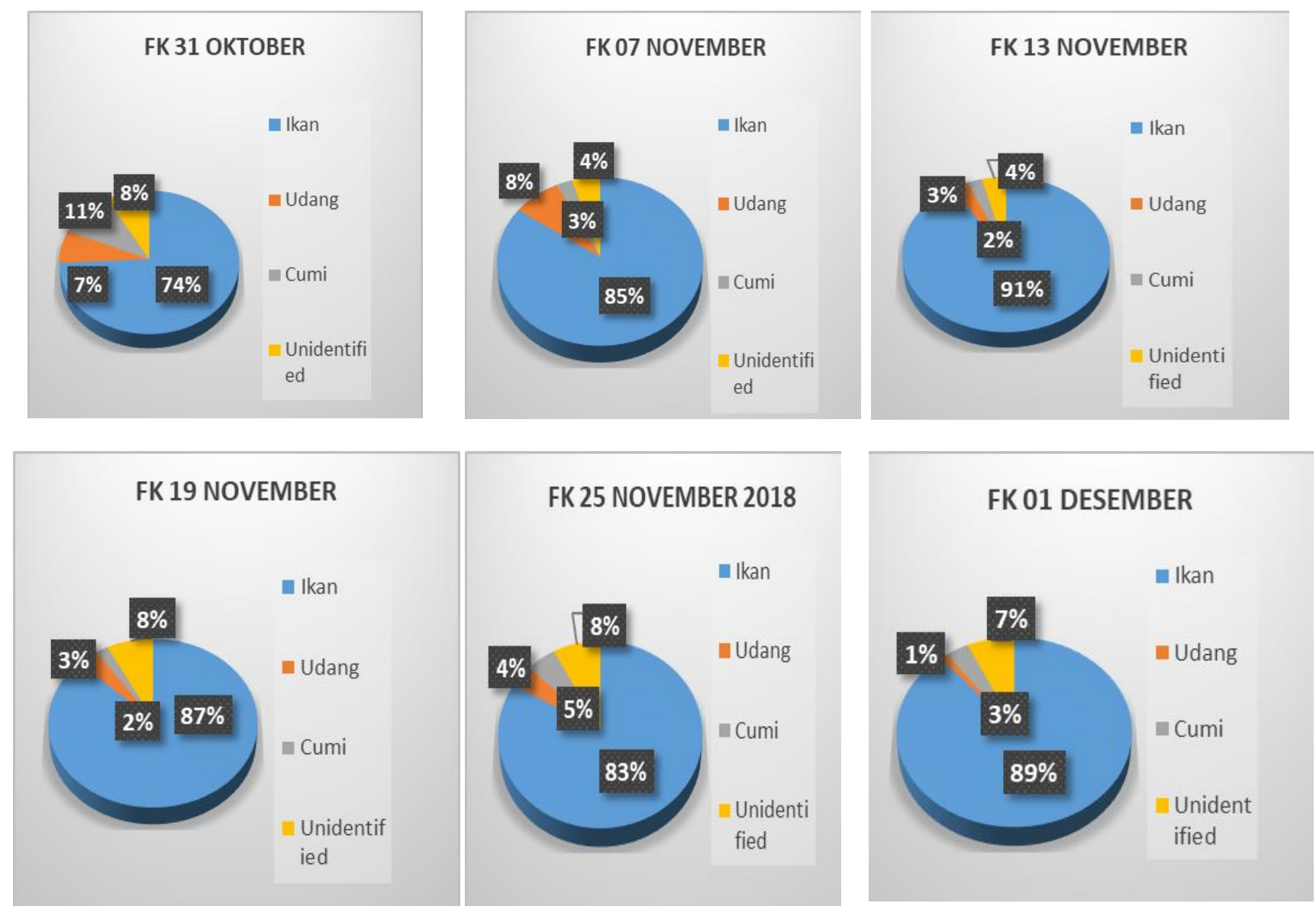

Gambar 5. Diagram Frekuensi kejadian Bulan (Oktober - Desember) di TPI Puger, Jember 


\section{KESIMPULAN}

Penelitian ini menunjukan bahwa pertumbuhan ikan cakalang lebih cepat daripada pertumbuhan berat ikan cakalang. Berdasarkan 107 lambung ditemukan organisme ikan, udang, cumi-cumi dan unidentified. Hasil ini menyatakan bahwa makanan dari ikan cakalang adalah ikan dimana dengan hasil persentase yang terdapat jumlah terbanyak.

\section{DAFTAR PUSTAKA}

Carlander, K.D., 1969. Life History Data on Freshwater Fishes of the United States And Canada, Exclusive of the Perciformes. 3d. ed. p.27-169p. In K.D. Carlander. Handbook of freshwater fishery biology, v.1. The IOWA State University Press, Ames. 397 p.

Effendie, M.I. 1979. Metode Biologi Perikanan dan ilmu kelautan. Yayasan Dewi Sri. Bogor. 112 hlm.

Food and Agriculture Organization [FAO] Fisheries and Aquaculture Department. 2006. State of the World's Fisheries and Aquaculture. Rome, FAO in Italy. 162 p.

Keren, W.L., Mantjoro, E., \& Wagiu, M., 2013. Nilai Ekonomi Sumberdaya Perikanan di Sulawesi Utara (Studi Kasus Ikan Cakalang). Jurnal IImiah Platax, 1(2):74-80

Merta S.G.I. 1982. Studi Pendahuluan Makanan Tingkat Kematangan Gonad Ikan Cakalang, Katsuwonus pelamis (LINN.1758), Dari Perairan Sebelah Selatan Bali dan sebelah Barat Sumatera. Jurnal Penelitian Perikanan Laut, 26:69-74.

Purwasasmita, R., 1993. Musim Penangkapan Ikan Cakalang, Katsuwonus pelamis, dengan Kapal-Kapal Huhate dan Pengaruhnya Terhadap Peningkatan Produksi di Perairan Sekitar Sorong. Jurnal Penelitian Perikanan Laut, 79:1-13.

Uktolseja, J.C.B. 1997. Laporan Penelitian Indeks Kelimpahan Ikan Tuna dan Cakalang di Sekitar Rumpon (Tidak Diterbitkan). Balai Penelitian Perikanan Laut, Jakarta. 29 hal. 